\title{
分析化学の誤差監理に対する統計の応用について
}

\author{
(昭和 27 年 4 月 16 日 受理)
}

$$
\text { 三 并三郎・荒川三干夫 }
$$

\section{[1]緒 言}

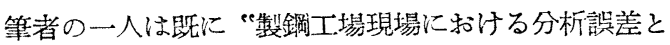

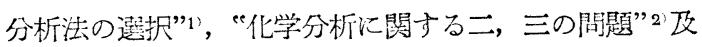
びその他三，三の報告中に詳細に論じたように，未知試 料の分析誤美は普通の既知試料の分析誤差とは桁違に大 きいものである事，且つこの巨大誤差はわれわれ分析者 にとってどうにもなら客観的拘束状態の下に発生して いる事，すなわち立派溶観的意義をむつものであり， これを打開するには分析化学が末知試料を対像とする科 学であるという意味で発剭すべき霖，このためには一つ の反忘の終点をその反応の前䄳に無関係に表示すべき確

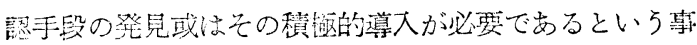
を示した。

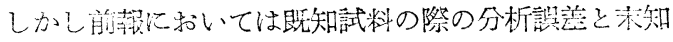
試料の際の巨大䛊差の聞の内的関連性改び前者より谽诸 への発星に刘して，どんな日子が具体的に関係するか等 についての瑟諭的取圾は行われなかった．本報ではこの 点の理論的取圾を行うとともに，嵒差統計は統計をとる べき具体的手䛼の葆化とともに質む大さも異るものであ

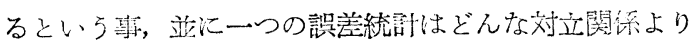
発生与ちるか，良って䛊差撲隇にはどんな “action”が合 理的に見出さるべきか，更に標準法の凟格について諭じ て兒よう.

\section{[2]化学分析の諤差の璉類とその大さ.}

化学分析の誤差の程度を知るには型通次の5つの䔬る 方法が行われて扣り．それに応じて誤差の種類並にそのの 大さが買る。

$\mathbf{A}$ 法：摡知の同一陚粼を同一時期に同一人が多数回連 続分析してその分析值の頻度曲線をつくり，それより平 均值並に標集偏差を求めるう法であり，以下これをA法 と呼ぶ事とする。この方法で見出される程度は一例とし て第 1 表に示すよ 5 に司成り小さく例えば Cでは $\pm 0.010 \% \mathrm{C}$ 前後であり，普通工策上注とんど問題とな

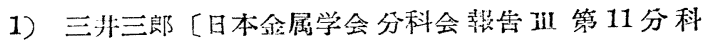
会 12 ]

2) I" ‘最近の分析化学近畿化学会編 1950.19]
第 1 表 A法：当所作業分析における一 (昭和 22-23 年度)

\begin{tabular}{|c|c|c|c|c|c|c|c|}
\hline & C & $\mathrm{Si}$ & Mn & $\mathrm{P}$ & $\mathrm{S}$ & $\mathrm{Cu}$ & $\mathrm{Cr}$ \\
\hline 本 均 值 & 0.38 & 0.2 & 0.53 & 0.01 & 0.038 & 0.17 & 1.04 \\
\hline 最 大 值 & 0.39 & 0.2 & 0.54 & 0.01 & 0.038 & 0.18 & 1.05 \\
\hline 最 小 值 & 0.37 & $0.2:$ & 0.52 & 0.01 & 0.036 & 0.16 & 1.02 \\
\hline $\begin{array}{l}\text { 最大值と最小 } \\
\text { 值 の 差 }\end{array}$ & 0.02 & 0.0 & 0.02 & 0.00 & 20.002 & 0.02 & 0.03 \\
\hline 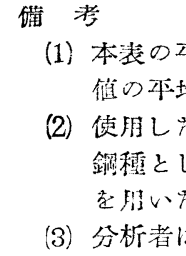 & $\begin{array}{l}\text { S均值 } \\
\text { 孛示 } \\
\text { 試料 } \\
\text { ては } \\
=8 \sigma \\
\text { ○一心 }\end{array}$ & $\begin{array}{l}\text { は备 } \\
\text { す. } \\
\text { は各 } \\
\text { ほと } \\
\text { であ } \\
\text { 熱細 }\end{array}$ & $\begin{array}{l}\text { 元素り } \\
\text { 元素y } \\
\text { んぞ } \\
\text { る. } \\
\text { 诸に }\end{array}$ & $\begin{array}{l}\text { 些異 } \\
3 ;\end{array}$ & $\begin{array}{l}10 \sim 20 \\
\text { 万\& } \\
\text { 䥃, }\end{array}$ & 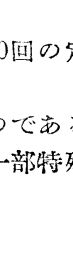 & $\begin{array}{l}\text { 定量 } \\
\text { 名侏, } \\
\text { 銅 }\end{array}$ \\
\hline
\end{tabular}

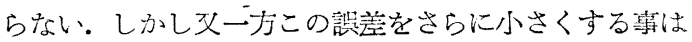
普通の際に分析法の根本的变化がないが゙り非常に困鿓保 である ${ }^{3)}$.

B 法：A法と全く同様な分析仕方ではむるが，但し熟 練者, 未熟練者等の数人の分析者に分析させて頻度泊線: をつく门，灭均倠並に偏差を求め，人による，熟練によ るこれ等の違を見る方法である.われわれのこの西年

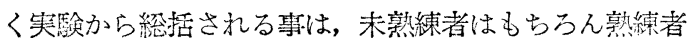
よりもバラッキの程度は大きいが，乙かしその大さはそ の一例として第2表に見るよ5に例えばCでは \pm 0.020 \% C を越えない，又場台により平均值が異る事もむる がそれも著しく小さく普通 $\pm 0.010 \%$ 以下で䜤に工秘 上問題とならない、未熟練者のバラッキが息外に小思い ばかりでなく，少しく熟練すれば熟緬者のそれにすぐ遣 付く，以下こ旮をB法と称する。

C法：同一の試䉼である置を分析者に知らしいて等い て，それを1日1個宛というようにとびとびに日常分析 の中に流してその誤差を調べる、この際の䛊洊は A， B

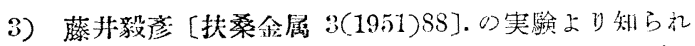
るように鉄鋼中のCを 士0.01\%より $00.001 \%$ 点差にするには既に酸素の Purification ボートの

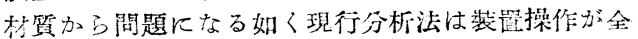

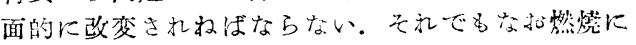
上るCの完全追出しの愦差は沫然である。 
第 2 表 B法：当所における熟練者未熟練者別による偏差の一例（昭和 $22 ２ 3$ 年度）

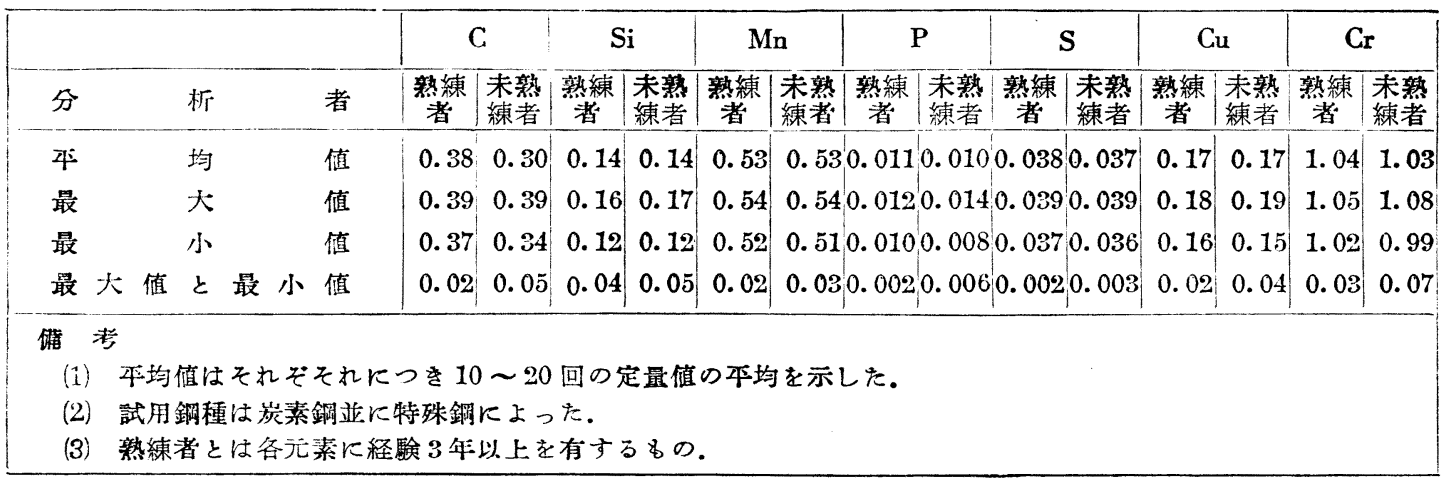

法のそれに比すれば試験期間の長い噤から例えば Cでは $\pm 0.020 \%$ を飛出し $\pm 0.025 \%$ を越える事的まれにはあ るが，多くの際には第3表に示す通りであり多く例を総 合しても $\pm 0.025 \% \mathrm{C}$ 以内の誤差内におさまっている。

第3 表 C 法: 当所において標準試料に扱入 分析した一例 (昭和 22 ～ 23 年度)

\begin{tabular}{|c|c|c|c|c|c|c|c|}
\hline & C & Si & Mn & $\mathrm{P}$ & $\mathrm{S}$ & $\mathrm{Cu}$ & $\mathrm{Cr}$ \\
\hline 平 均 值 & 0.38 & 0.1 & 0.67 & 0.015 & & 0.17 & 1.04 \\
\hline 大 & 0.39 & 0.16 & 0.62 & .015 & 0.039 & 0.18 & 1.05 \\
\hline 最 小 值 & 0.36 & 0.12 & 0.60 & 0.013 & 0.037 & 0.16 & 1.02 \\
\hline $\begin{array}{l}\text { 最大值と最小 } \\
\text { 值 }\end{array}$ & 0.03 & & 0.02 & .002 & 0.002 & 0.02 & 0.03 \\
\hline \multicolumn{8}{|c|}{ 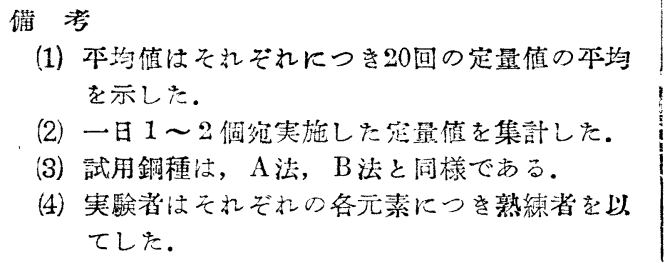 } \\
\hline
\end{tabular}

以上A-, B-, C 法の誤差は試料が既知である， 文少く とも同一である事が知られているので正磪な主観の全く 入らない謂差の data をとる事は難しいが，しかしその 誤差の程度の大きくない事だけは事実である。

D法：同一試料である事を分析者に知らさないように して日常分析の中にとびとびに混ぜて長期間にわたって data をとる．文は故意に試料の形状その他を变え別な 試粼であると称して分析させて data をとるという方法 である.この方法では A-,B-, 及は C 法からは全く想 像もできないような大きい誤差が，乙かも非常に高い頻 度をもって生ずる。この事の一例は第 4 表に見られる通 りでめり例えば Cでは鋼種により な謂差が生ずる事は容易に見出される.さらにこの誤差 は大きい将かでなく元素によってその方法が黑るとい う特長をもつし，この出現は鈵種とも密接な関係卆有す る.どうしてこのような大きい䜋宏がしかる大きい頻度 在もって起るのかは従来訪明ができてない。

日常分析の㤑に標準試料が必要に応じての都度流さ れているので試薬や身体の調子の变化等からこのような
第 4 表 D法: 当所作業分析に行方しめた未知試料比較分析中特に誤 羞の今じたもの一例

\begin{tabular}{|c|c|c|c|c|c|c|c|c|c|}
\hline 試 & 粼 & C & $\mathrm{Si}$ & Mn & $P$ & $\mathrm{~S}$ & $\mathrm{Cu}$ & $\mathrm{C}_{\gamma}$ & [註] \\
\hline \multirow{4}{*}{$\begin{array}{c}\text { 崖素跲 } \\
\text { A }\end{array}$} & 1 & 0.25 & 0.44 & $0.6 ?$ & 0.02 & .014 & 0.18 & 0.10 & \multirow{4}{*}{$\begin{array}{l}\text { (1) 如何なる元素に巨大 } \\
\text { 誤遥が出るかは， } \mathrm{A} \text { ， } \\
\mathrm{B} \text { 法からはほとんど見 }\end{array}$} \\
\hline & 2 & 0.23 & 0.43 & 0.69 & 0.02 & .015 & 0.22 & 0.10 & \\
\hline & 3 & 0.24 & 0.40 & 0.69 & 0.02 & .015 & 0.22 & 0.14 & \\
\hline & 差 & 0.02 & 0.04 & 0.06 & 0.00 & .001 & 0.04 & 0.04 & \\
\hline \multirow{4}{*}{$\begin{array}{l}\text { 炭素鏏 } \\
\text { B }\end{array}$} & 1 & 0.69 & 0.32 & 0.79 & 0.06 & .027 & 0.15 & 0.17 & ミつかな \\
\hline & 2 & 0.66 & 0.31 & 0.85 & 0.06 & .032 & 0.18 & 0.15 & \multirow{3}{*}{$\begin{array}{l}\text { (2) 各元素によりその出方 } \\
\text { は異なる }\end{array}$} \\
\hline & 3 & 0.73 & 0.31 & 0.86 & 0.06 & 0.035 & 0.19 & 0.15 & \\
\hline & 差 & 0.07 & 0.01 & 0.07 & 0.00 & 0.008 & 0.04 & 0.02 & \\
\hline \multirow{2}{*}{$\begin{array}{l}\text { 岸素鋼 } \\
\mathrm{C}\end{array}$} & 1 & $\begin{array}{l}0.67 \\
0.77\end{array}$ & $\begin{array}{l}0.43 \\
0.36\end{array}$ & $\begin{array}{l}0.60 \\
0.62\end{array}$ & $\begin{array}{l}0.03 \\
0.03\end{array}$ & 0.039 & 0.19 & 0.12 & \multirow{7}{*}{$\begin{array}{l}\text { (3) 鋼種の変化によって巨 } \\
\text { 大愦差の出方む又異な }\end{array}$} \\
\hline & 差 & 0.10 & 0.07 & 0.02 & 0.00 & 0.002 & 0.02 & 0.02 & \\
\hline \multirow{5}{*}{ 鉎 鉄 } & 1 & 3.43 & 1.82 & \multirow{4}{*}{\multicolumn{3}{|c|}{$\begin{array}{l}1.380 .0330 .016 \\
1.370 .0280 .019 \\
1.310 .0290 .021 \\
1.350 .0300 .021\end{array}$}} & 0.04 & 0.04 & \\
\hline & 2 & 3.22 & 1.75 & & & & 0.03 & 0.03 & \\
\hline & 3 & 3.16 & 1.83 & & & & 0.02 & 0.06 & \\
\hline & 4 & 3.36 & & & & & 0.04 & & \\
\hline & 盖 & 0.17 & 0.18 & \multicolumn{3}{|c|}{0.070 .0050 .005} & 0.02 & 0.03 & \\
\hline
\end{tabular}

大きな䛈差が告ずるもので ない事は明然である。この ような普通の条件の下では 起りそ5もない愦羙が生じ た際には，われ学れはその 愿因をあれこれ過去にさか のぼって調べ上げる.

Cの高い方のこのような 巨大誤差が発生したときは 試料に油が附着してなかっ たか, 刷毛が混入してなか ったか, 或は活れた手でボ 一トを掝まなかったかとい うよらな事が，又Cの低い 方の誤差が生じた時はゴム 管に鼠裂がなかったか，気 空に異常はなかったか等が 
すぐ問題にされやすい.このような問題の分析過程に入 ってくる機会を完全に排除するという事は不可能に近 く, 従って遡及して原因をさがせば必ず何かの問題が 思い出されるのが常である. しかしこのようなとんでも ない專がこのD法の誤差の原因だとすれば，その発生頻 度は著しく小さい梳である.すなわち結果からの原 因を類推するときはこのような万一の事故だけが考えら れ灭このような事故のあった例だけが記憶に残り, 従っ てD法の誤差はこのような不注意に類する原因によって 起ると考学られやすいが，乙かし発生頻度とい5量的の 面より考えれば原因は，このような簡単なものではない という善は明瞭である.

われわれが故意に5.その暗示を与えて分析させたとき 直ちに又は少い再分析で反帰してくるほど熟練者で岕 り，未熟なほど自信のないほど再分析の回数が多い。 同様に䛊差結果を見るとき未熟練者程この種の誤差を犯 す事も又われわれの統計上から明膫に知られている.

E法*：未知試料を各分析窒に配布して分析させ，そ の結果を集めて知る誤差である.この際の誤差は一般に D法のそれよりも大きい.この䛊差は各分析室の分析者 がその結果に基いて話し合えば次管に小さくなる性格を もつばかりでなく，不思議な事には各分析室の最熟練者 が可及的厳密な注意の下に多数回分析し最も妥当な平均 值を持号寄ってしかも大きい偏差の生じている事更び各 1 カ所の data の内のバラッキは何れも第 5 表に見られ

第5袁 $\mathrm{E}$ 洙：同一試料比ける各所比較の一例

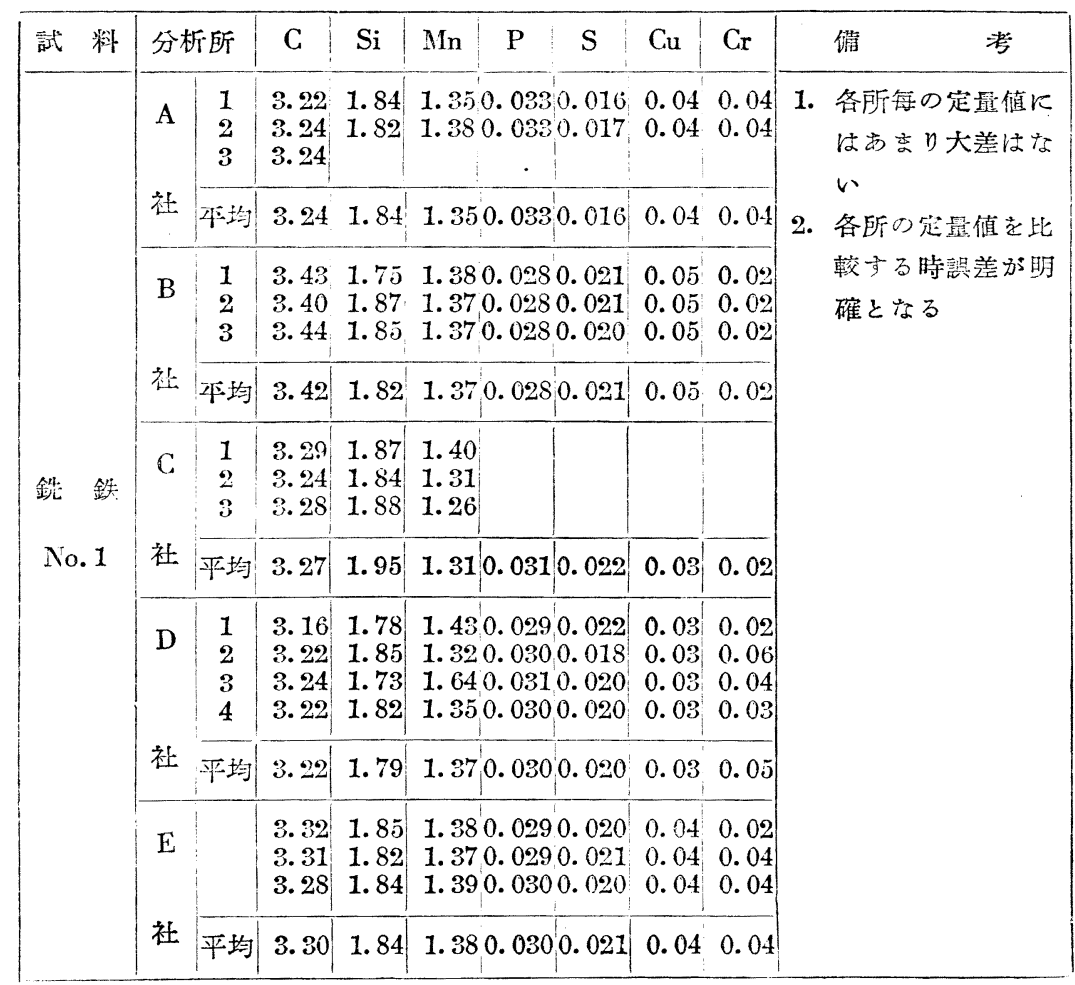

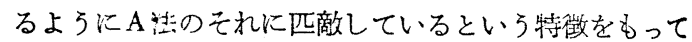
いる、すなわ方 1 力所における分析者の熟練の程度は物 をいわないで，各分析室の分析法の中にその誤差の原因 があるという事が知られる。

われわれ工場分析者は商売上の取引との他の関係か ら，このような他流試合に可成り多く遭遇寸る。これ等 の他流試合の結果より次のような事が詔差の原因である 事か知られた。すなわちC分析では吸収剤としての固体 $\mathrm{NaOH}$ の貨, 大さ, 及び詰め方等4>Pの JES 法ではHCl の追出しの程度の見別け方の差異 ${ }^{1}$, Volhard の Mn 分 析法では添加する $\mathrm{ZnO}$ の質及び量の差巽 $\mathrm{S}$ の重量法 では Blank 検定に抢ける $\mathrm{H}_{2} \mathrm{SO}_{4}$ 添加の有無又は静置特 間の差暴等で知られるように7, 分析法における確認手 段の明瞅でない処に又は影響の程度の小さいと考えられ やすい操作によって意外に大きい差異が生じているとい う事がわかる。

以上の外に例えばわれわれの製造所で行っている方 法, すなわち現場分析室で取鍋試料を分析し，その分析 值を示させる事なく同じ試料を研究課分析室で分析し仙 者の值を比較するというような方法すかる。これは両分 析室が日常作掌として流している分析て比䩙を行うとい う方法である。この比較分析得られた結果は例えば $\left(\mathrm{NH}_{4}\right)_{2} \mathrm{~S}_{2} \mathrm{O}_{8}-\mathrm{As}_{2} \mathrm{O}_{3}$ 法による $\mathrm{Mn}$ 定量法?では $\mathrm{HMnO}_{4}$ 発色時の液量が 100ccであるか, 又は60〜 70cc であるか というような，分析者が大して反応に影響しないだろう と漠然と考えたような操作 の中に大きい誤差が発生し ていたといら事 ${ }^{3)}$ や夜間 に括ける加熱板の高熱によ って誤差が生じたとい5よ らな專も知られた ${ }^{9}$ ・㤐な わち分析時間の制限や能率 向上のため政变を余儀なく された分析法の中で，しか

* 本法の䜁差に就いては既 報を参与され却い。

4) $\mathrm{NaOH}$ の質, 大さ, 詰 め方で如何に諆差が生 ずるかは桐山，荒川 [日本食属学会, 昰利 27年春李大会䄍演了に 報告し光

5）実罂にわれわれは2回 もこの例に漕遇してい る

6)桐山〔日本金属学会分 科会報告] V-C(1252)

7)われわれは戦前この事 に対する不注意で裁判 分析に败九た事がある 
も分析者が理論上大した影響なしと漠然と考えたような 操作の改变の中に誤差の原因が見られた例が多く，われ われが最初頭の中で考光たような単純な全く偶然的な原 因による䛊差発生の例は意外に少なかった。この方法は むちろん E法の一種である

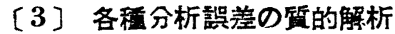

既述のように D-, E 法の摆差は A-,B-,C 法のそれ に比すれば妳違に大きいるのである. しかし分析誤差に 関係すると思文れる一つ一つの因子を採り上げて行くと きは，熟練度でも装置でも文は試薬でも或は操作法でも 特可或は故意に極端な差異をつくらないかぎり，その分 析過程から D-, E 法に見られるような巨大誤差は発生 しそうに思われない，従ってD法の説差だけより見れば 巨大誤差は全く個人の注意力で定まり，偶然的なるの或 は極端な不注意によって起るというよ5に考えられる。 だがE法の䛊差を併せ考完るとき，この巨大㗪差は偶然 的性㭲を全く払い栔てて分析法それ自体の中に明かに内 在してしまう事が知られる。すなわち D-, E 法の巨大 誤差は分析過程中に発生せねばならないが, 又分析過程 の汇はその発生原因が求めらるべくもないという䦗題 が生ずる。

そこでもら一度分析誤至は根本的に考え直さねばなら ないという事がわかる。

\section{1. 誤差の啠的取扱}

一つの試料を多数回分析し，分析値の頻度曲線をつく れば周知のように Gauss の Error Curve ができる、こ の際われわれは分析值を頻度という意味で量的に取扱っ たわけである.すべての堏合に量的に取扱われるには， まずそれが同一の質に還元され，その質の下に始めて量 的に取扱われ得るものである. 今同一試料を分析して なる值が $x$ 回，b なる值が $y$ 回出たとする，a 及び bが 出現する割合が各々 $x$ 及び $y$ として量的に表わされ比較 されるからには，まず $\mathrm{a}$ 攻び $\mathrm{b}$ の出現が同一の出現能力 に還元され，その能力で測定されるとき $x$ 及び $y$ となっ たという事が背後に潜んでいるわけである.

a と b とは何等の共通性も持たない独立事象である. 刃その出現には非常に多くの因子が相互に入り混り且つ 密接な関係をもって結ばれ，その各ふの变化は $\mathrm{a}$ 攻び $\mathrm{b}$ の出現に影響をわつ.すなわち単独にはその強さを取り 出す事のできない多くの因子が関係し，その総和として 出現能力が $x$ 及び $y$ で表現されるという事である.

同じ試料のCを定量してそれが $0.18 \% \mathrm{C}$ と出るか, $0.16 \% \mathrm{C}$ と出るかに就いてはいろいろな条件が作用す る. 周知のようにCの然㜔定量法は試料を酸素気流中に

8) 川村弘一[学振19委 1 分科会 2037]

9) 細田 [未発表]
桨焼し，出てくる $\mathrm{CO}_{2}$ を捕捉して定量する，この際定 量に哭係する因子としては（1）酸素又はボートその他 の使用器具の Blank Z支び試料の偏析或は油ての他の附 着等, (2) 試料の組成, 大さ, 然焼湿度, 酸素の純度, 一流通等の総合作用による試料残椬中よりの C の追出 し, ( 3 ) $\mathrm{CO}_{2}$ の他物質による吸着損失並に $\mathrm{CO}_{2}$ 以外 の妨害物侹の飛来，(4) $\mathrm{CO}_{2}$ の完全捕捉並汇測定とい 万大体 4 つの闍題が考えられる.これ等の定量結果に対 する影響仕方はえの都度変化するし，又これ等の間の相 互作用の強さも变る.このようにしてての变化に相応し て個ふの価は個别的となる。

理想的状態を考兄て見よ5，Cの定量には前記のよ5 に非常に多くの因子がしかも相互に切離す事のできない 染接な関繁をもって関係しているが，そこに流れる自然

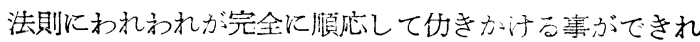
ば誤差はなくなるはずである。この事は試料がどんなる のでめらうと装置が如何であろうと变りない，但し自 然法則の在り方はわれわれの具体的仍きが方によって 一变する，從って誤差とは試料，装置等がすつ因果の法 則とわれわれの仂きかけ方の相対立する相互関係より成 立つ又はこれ等の因子に分解できる。すなわ台誤崖は対 袁に対するわれわれの仂きかけ方の合法則性入は自由の 程度によって規定される。このようにしてa页はbは自 然法則に対するわれわれの仂きかけ大の合法則性文は自 由度という同一の質に還元されて，その量によって测定 されるとき $x$ 及び $y$ という出現能力をすつるのとして現 れるわけである。

以上の事より次の事がいわれる。すなわち，

(1) 同一試料刘する同一条件の下で, われわれ

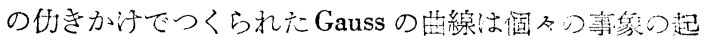

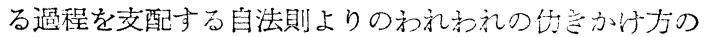
ズレを表現するものである.

(2) 同一陚料比する質的に異る条什心下のわれわ れの㭊かけでできたGaussの曲線はこれて祀地して質 も大さも翼るものとなる。

（3）われわれは誤差をなくするために淕自然法則に

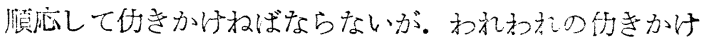
は事爱の起る自然法則の在り方をも亦变化已心。. 位っ て始めから法った一定の誤差の原因というものが存在す るのでなく，䍀差の原因及びその対策というものは具体 的仂きかけ力とともに变ってくる。

\section{2. 各分析誤差検定法により見出される誤差の賣的差} 異

A-, B-, C 法と D-, E 法における最も大きい美晎は前 者は既知試料を対嗦とする，或はそれと同様条件の下の 分析であるが，後者は試料が未知であるという处にある と考劣られる.そこで前記の事より既知であると末知で あるとによってどんな差がわれわれの䚮きかけ方の甶间 
の中に生ずるかを検討すればよいという事が解る.

\section{a) A-, B-, C 法とD法との盖異}

既述のようにD法は試料が同一である事を分析者に知ら しめないよ5にして，日常分析の中にとびとびに入れて 流してやる方法であり，C法は同一試料である事を分析 者が承知して同条件の下に流すという方法である．後者 では分析者はその試料に対する経験を思い浮べる事がで きるが，前者では事情は異り過去の経験技術の総合から どんな試料にでもあてはまる概念を引出し，その概念沉 従って仂きかけざるを得ない．俗事にたとえれば相手の 出方の決った練習の将棋を打つ場合と真剣勝負の相手の 出方が打って見ねば解らない将棋をらつ際の差である ${ }^{10}$.

A法に従って分析するとき，例えば $\mathrm{C}$ 分析では然燒温 度，酸素流通速度等の具体的仂きかけ方は可成り一定に 保てるので一定の試料ではそれに相㐫し一定した定罫が 可能である，B法による際の未熟練者もこの程度の事は できる.すなうら算に前回の力法を真似るという事で心 り,ここでは試料に相応する具体的操作を打つというの ではなく，既に具体的操作が在り，それを真似るという 事である，C法の際には剖回の操作を真似る事又は思い 出す察はA-, B 法の際よりは難しいであろう。しかし全 く未知䚽という事とは異る。

未知轿粉の分析では常に相手の出方が考慮に入り且つ どんな試料でもわれわれの彻きかけによって亮服されね ばならない。す尓わ救める元素の量的差以外の他の因 子による前歷の差が㧹止されるような具体的仂きかけが 加えられればならない：これはわれわれの具体的仂きか 㺭方と乞の結果の観察とに基く自己の経験, 技術に立朋 して始めて獲得でさるものである．例兄ば然焼法による $\mathrm{S}$ 定署では“理論的に考えれば何にも燃焼残渣が完全に 螾融するとい5必要なく或る温度或る時間保持すれば $\mathrm{S}$ は $\mathrm{SO}_{2}$ となって完全に追出せる”といわれるか子知れな いが，現実において未知試料では完全追出しは“燃焼残 渣が㟈全に熔融する”という試料の組成，形状の如何に かかわらず，換言すればこれ等の前暨の差が揚止された 状態まで持って行かね样量は完全とはならないのであ る. 石炭中のS 然焼法に対する A. Seuth の長年月にわ たる分析の結果における対策その他の実際分析者の経験 の歴史は明膫にこのような“燃焼残椬が熔融する”事が 常に正しい結果を出すための不可欠な条件である事を物 語っている。

10）厅能な处法はないとは昔よりいわれる格言である。 特棋でる团基でる始めより決った絶対飞敵に勝つ和 法はない，定石とは相手の山方が考虑されてできる 手であり，锭って相手次第によって無限に成長する 一つの手法である。分析法とはこの定石に相当する 無限に発展する方法であり，固定されているすので はない。
以上の事より次の事が推定せられる.（1）既知試料 の際には熟練度は大きい因子とはならないが，未知試料 では実践の経驗が非常に大きく関係する，(2) 未知試 料では所要元素以外の量的差以外の他の因子による前歴 なは完全に揚止されるような強力な仂きかけ方が不可久 とる.この前歴の揚止は試料の在り方に質的变化を生ず る.この買的变化は分析の正常な進行を指示する確認手 段となる.（3）分析法という立場よりは既知試料の誤差 と末知試粼の誤差との差はとの分析法における確認手段 の発見页汢これが積極的導入の容易さととも減少するで あろう。（4）D法の巨大誤差はこの確認手段が分析法 の中に物体化されてないときに起っている䛊差である.

\section{b）A-,B-,C法とE法との差異}

$\mathrm{E}$ 法法D法と同栚に和知試料であるが，さらに $\mathrm{E}$ 法で は各所の分析法に差晎があるという事が問题となる。各 所の分析室は备々自己をとりまく異る環境の下に分析法 を巽にし页改变している．だがしかし各分析室はどこで

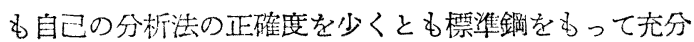
に検討し使用しているわけである. 従って簡単に㫴えれ ば標準銅での結果より未知試料でもその分析值は各所す ベて一致し，良ってA法等の䜋差と全く同じであるべき と考えられる.しかし晲实にはE法の愦差は普通D法の

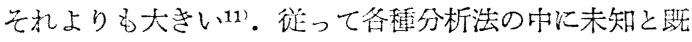
知において異る共通な何物かが見出さるべきもので岕 る. 既述のよろに未知試料では実践の中より得たすべて の試料にあてはまるべき操作が必要であり,この操作の 中には化学反感の合理性ばかりでなく，試料の前歴の揚 止という事が含まれている，化学反忘に対する合理性流 普通の分析法では注とんど大差ないと考えられるが，前 歴の場上の程度文はその確垫の容易さは可成り異る.し かも分析は一ぺんの操作で終るわけのものでもない.こ の㝵によりこの揚止の程度の差は次の反応の合理性に強 く影響する.このようにしてE法の誤差は各分析室がす つ確認手段の皤類, 精度及び数並にこれに相応する具体 的仂きかけ方と不可分の関係をもっという事が知られ る.

以上の事を総合すれば（1）各分析室は標準試料では 大差ない傎を出すが，末知試料では大きいバラッキを生 ずる. (2) 一力所内の䛊差は熟練, 未熟練, 注意度, 分 析回数により大差なく $\mathrm{A}$ 法, B法に等しいので, 各所の バラッキはその分析法の中に物体化している.（3）各 所の分析法はすべて翼るが，整準試粼での值は一致する

11）1900年頃の独选その他の圆の比較分析と戦時中の日 本の学振の比較分析でも明嘹下大きい事が知られ た。な和この而者の比較分析結界よりこの誤差はこ の期間に㾏とんぞ減尘してない事が知ら机炎。Mn, P,Sの如きは実に 100\% い狂いが生じていた。詳し (は 1). 2) の文献参照. 
ので，E法の誤差原因はその分析反応の中に求められる べきものでなく, 各分析法において未知と既知とい5共 通問題より生ずる試料前暨の揚止の程度の中に生じ，そ れは確認手段とし分析法の中に物体化としている.(4) 前歴の揚此は買的变化を伴うのでわれわれの目前にあり ありとその姿を現している.（5）各分析室の值の浽当性 はこの確認手婜の合理性, 数等によって定亲る。この確 認手段は各分析室が比較分析, 溒判分析等の他流試合の 結果として獲得してきたものである。（6）この上うな 確管手段の存在が比較分析の值が一致するために不可欠 な事は独凂鉄鉔委員会の $\mathrm{S}$ 燃焼法等の結果に明瞭に指示 されている。

\section{〔4〕各種分析誤差の量的取报いと “action”につんて}

前章に执いてわれわれは䜋差を質的にのみ取放ってき た. しかしすべてのものは質と量によって始めて完全に 表現されるように，䛤差す又赈と量の闭面より取圾われ るべきるので心る。

貺述のように愦差は“対象における自然法則”と“そ の法則に対する合理的なわれわれの仂きかけの自由度” といら相対立する因子に分解する事ができた。しかし誤 差減に刘し如何に仂きか外るべきかという“action”

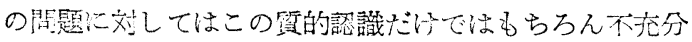

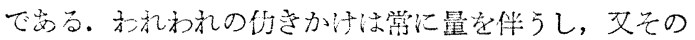
量は一定限界をもって筫的变俣を引起すからである。

䛊美を悬的に取扱わんとするとき直らに䦗題となる事 は,誤差は必然的に起る偶然量で岕るという事である12。 換言子れば誤差はすべての湘定に共通に起る性格をるつ が，ての大さはすべての測定に䚱てて暴り，測完值の個 ふを嫢定する性格をもつものである，更に比較分析の結 果より知られるように巨大誤差の偶然翼の中では全くの 偶然的要素は，ほとんど問題にならないという事が知ら れている. 従って巨大證差13'において問題となる偶然と いうるのをさらに明確に規定する必要がある。

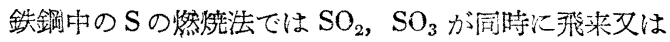
発生する酸化鉄又は $\mathrm{MoO}_{3}$ 等のた燃焼管の出口又はガ ラスキャッブ或は滤過装置等で吸嚆され著しい損失を引 起す. $\mathrm{SO}_{2}$ 等がこれ等酸化鉄及 $\mathrm{MOO}_{3}$ に吸着されるに は種及の条件がある.これ等の結唱の在り方, 湿度 $\mathrm{SO}_{2}$ 等 の分圧，接触時間等. 接触時間を短かくするようにただ 単に酸素の流通速度を増すだけでは吸着の防止はできな い。わわれの実験によれば滤過装置をできるだけ低温

12)との事注誤差が Gauss の分有を示すとか, Poisson 分布を示すとか, 或は Poisson 分布は Gauss の分

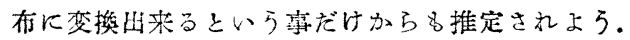

18） D法の俉差もそり発生頻度並にC 法の非差の小さい 事より考えれば同様に一般に考えられているような 全くの們然的なるのとは将えられない。
部に取付け且つ軦射をさける事，ガラスキャップの形文 は流速等をかけて気流中に瀜流の生じないようにす る，又はてのように操作する事によって吸着損失を最小 限に押える事ができた。

形状複雑なる罢置中に気体を或る速度以上に流せば必 然的に洞流を生ずるが，渦流の強さそのものはその時の 速度装置の形状等によって支配される偶然晴であり, 且 つ各々の測定に対し個別的である. 渦流によって酸化鉄 等の吸着物は高温部に附著するようになり又 $\mathrm{SO}_{2}$ 等との 接触の機会も亦增大し, 従って他の条件が一定ならば渦 派の強さに相応して吸着損失の增大が起る.すなわらこ のような際吸着損失は必然的であり且つその吸着損失量 は伿然的であり個別的である。るちろん吸部は酸化鉄等 の在り方にも関係するが，もしこれ等の条件ぶ一定なら ば吸着はほとどこの瀜流の強さに比例する. 従って吸着 の量化はこの渦流の大さによって行われ又涓流の制御に よって䛊善の防止が可能となる。同様な事柄は沈澱分離 の際にむいるれる，顸澱は必ず特定の晶㾕及び大さをも って出現すふが，その晶癖及び大さ等はその時の溶液の

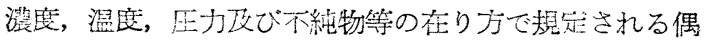

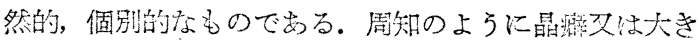

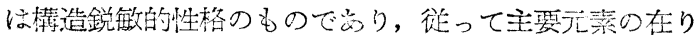
汸かでなく，不純物元素の在り方によってどうにで もなる性格のものである。啍って他の条件が一空ならば 溶液宁の不純物の在りちによって曼着は定末り従ってこ れが量化の対象となり又これを制御する素が正常な沈搌 分離のための合理的効篗である.な执このょうな事は分 析過程中並に分析以外の專柄にも幾多見られる14.

以上の上らにわれわれが一つの方法をもって対象に仍 きかける時は対象はこの仍きかけによってその対立物に 分解される。往って必然的なもの以外飞必ず偶然的なる のが発生し，この偶然量はわれわれの目的に対しては誤 羑として出現するという事柄でありこのようにして最大 の注意をもって繰返した多数の分析值の平均が，しかも

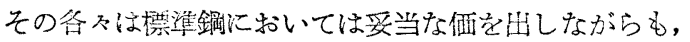
なお末知試料では大きい誤差をつくるという事が部明さ るべきものである。これをC然燒法の巨大誤羑について い党ば然焼すれば試料中のCばかりが酸化されるわけで なく試料中の $\mathrm{Fe}, \mathrm{Mn}, \mathrm{Si}$ 等も必ず酸化され，できた酸化 被膜の特理的在り方はその時の条件により個別的であり 且つその被膜の在り方は試片の完全酸化又は C の追出し に対し圧倒的に豎係する。このようにして酸化物残渣が 固体で第るときのCの追出され方は备々の測定によって

14）例えば液体圭凝固させれば液体中には必然的に沽流 が起り旦つその大さは偶然的であり，凝固速度の計 算よりバラッキが起る。或は $\gamma$ 中より $\alpha$ が析出す るとき $\alpha$ は $\gamma$ とは必ず異った密度をる⿱十口旦つ特定 の形態をとりしかもそれは偶然的である等及。 
かなり大きい变動を示するのであり，彷って檩準鋦に括 ける妥当な操作条件です未知試料の定量は著しい变動を 起寸等が知られる15)。このよ5にしてこの変動従って誤 差を少くするには残盜の完全熔融が不可欠なものとなっ てくるのである。

必然的に発生する偶然量を拥える手段は必ず対鲙に筫 的变化を起させねばならない，すなうす操作の連続的な 变化によってもたらされる質的变化が巨大誤差授減の確 認手段であり。このような偶然量の制御は天然の中には 普通存在しないで，われわれの積極的な仂きかけによっ て始めて得られるものでまる。

このようにして巨大誤差撲隇の action は (1) 我ふが 刘象に仍きかけるとき必ず発生する偶然因子を見付ける 事，（2）これ等偶然因子の中どれが最も大きな問題と なるかを客観的に取上げる專，（3）この偶然因子を制 御するように具体的に装置, 操作を变光る事, (4)こ のような制御によって筫的变化が起るところまでもって 行く事，（5）この意味での磪諗手段はただでは存在し ないので，われわれは一つ一つの具体的操作の中にこれ を積極的に導入する事で㐫る。

\section{〔5〕標準法としてどんな分析法が選ばるべきか？}

同じ Mn 分析法でも Bismutate-, Volhard-, $\mathrm{As}_{2} \mathrm{O}_{3^{-}}$ $\left(\mathrm{NH}_{4}\right)_{2} \mathrm{~S}_{2} \mathrm{O}_{8}$ 法等の各種の方法がある。 その各々の分析 法には必ず一最一短があり文必ず一定の誤差をもつが。 一方標集法とは何時, 何処で誰れが行っても他の力法よ りも正確である必要がある。既述のようにA法に抢ける 愦差はわれわれが問題とする分析法では，ほとんど常に 工業上許容されるものである. 従って特定分析法が標淮 法であるためにはD法，E法の誤差が他方法よりも小さ いという条件によって定市られる。この事は規格法制定 の際，それがほとんどすべての際に比較分析法にかけら れて審請される事でも明かであろう。

巨大䛇差撲隇の方法は既述のように必然的に起り且つ その强さ俚然的な因子を制御するように致置及び操作を 改变し，しかもそれにより対象に質的変化を起させると ころまで持って行く事にある.すなわちこのような質的 变化の確認方法を一つ一つの操作に積極的に導入する事 により始めて誤差の量化並に媄隇が可能である。

未知試料の分析は常に相手の出方が考慮されねばなら ない，従って㯲集法とは㭘も相手の出方が充分に荖慮さ れた上でつくられた将棋の定石が他の分析法のそれに優 っているというょうなものであら枋ばならない，定石を

15）試料の燃燒が，酸素の純度で如何に変るかは gas 切 断の試験が明暸に物話って扔る. $99.5 \%$ の純度と 97 \%で切断速度が 2 3 倍も買るといら報告がある。 試料の組成に上る善もるちるえある。ての事からす 未知試料ひ取报が如何火難しいかがすかるう。
つくるには真剣勝負が必要で岕る。すなわら他の条件が 一定ならば真剣勝負の度数によって良い定石はでき上 る. 従って経済的に重要性をもつもの㴗ど又何肌の分析 室でも使用されているほど立派な定石をもっているはず である，工場において分析法が選ばれるには，正確度が 同じならば迅速で能率的な分析法が採用される，分析の 正確度, 迅速性, 能率は分析法によって渭定されるが。 これ等の要求はすべて分析外の条件によって起る。この 対立関係により正確度のよいあのが，或は迅速能䒚的な ものぶ選れ，そしてそれが外的要求の下に短所である各 ふ迅脨能率化が或は正確化が研究されて所要の肙的に合 致するようになるのが，分析法発桪の歴实である。この ようにして，より研究されたものが㰖準法たる性格を獲 得し新しく生れ標準法となり，要求に合わなくなった， 研究されない分析法は死隇して行く.

外的装求により分析法は新しく生れ, 又死減するわけ であるが,この外的要求は工業の進歩とともに前進する。 従ってかって過去の時代に法摆準法としての立派な性格 をもっていったものでも今は全くその洒值に相応しない ものがある. Fe-Mn 等の分析洼に㧍ける Bismutat 法等 はこの例であろう。この方法の煩雑さ非能率性等により 殆によりほとんどすべての其剣勝負をしている分析室で この方法を使用されても抢らない父研究されてもおら ないからたせる。

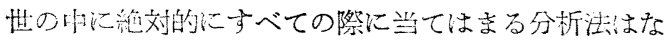
い. 苳って天下り的に特定分析法に分析法を統一寸ると いう轷は行うべきbのではない.かくして分析法の繥一 も又前記標準法と同様で，分析法をとりまく環境の矅析 が行われ且つ分析法自体に内在する愦差原因が特に昆大 註差という点で梌討されその上で迅速能率的な方法にと 統一されるべきであろう．結諭的にいえば谷所ばらばら な方法で分析させて特く事は分析䍃督者として高無能で あるが，天下り的に一つの分析法学ただ拥しつ汗徱準法 とし双はそれに統一するという等も又 easy-going な機

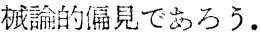

\section{[6] 結 論}

分析を監理する上には先ず誤差の統計をとらねねばなら ないが，愦美はその誤差を求めようとするわれわれの具 体的仂きかけ方，すなわら sampling の方法の罢るに微 いわれわれの前に筫も大さも異ったものとして現われ る. 化学分析では普通ら通の異る sampling によって䛊 差が check されており，その备及によって得られる䛣 差の間には著しく質的にも量的にも珪がある。

既知試料を対像とする普通行われているち法で韭差を 求めても未知試料打いて発生する誤差は解らない，又 熟練の尊さ, 実戦の勇士の経験の有難さも解らない，そ れは誤差の質が全く暴っているからである、未知試料に 
おける巨大誤差は一般に考えられているような全くの偶 然的なるの入は不注意より発生するものではない，未知 試料の分析では既知試料のそれと暴り相手の出方が考慮 されねばならないすすなわらすべての際に志てはまる方 法従って理性的諰識に立脚する操作が必要である。この 際江注意す心゙き事は，対芜試料は常にわれわれの前化化 学的性質の反をもつ物体としてではなく，同時に物理的 性望をももって现れ，多くの例が証明する如く閴者の性

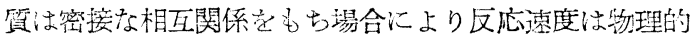
性質だけで規定される䈞がある。この事により一般に分

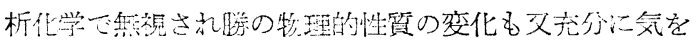
つけるべきで出る事が知られる。

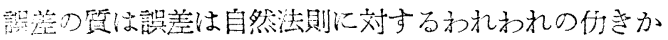
けの合理性とい万対立因子红分解でき，われわれの仍き

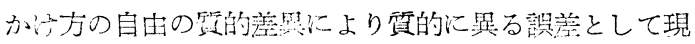

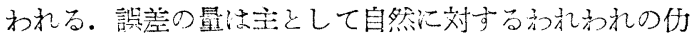

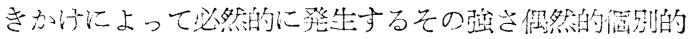

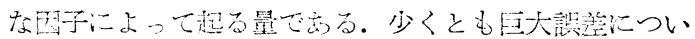

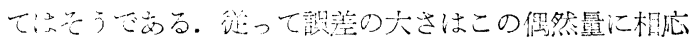

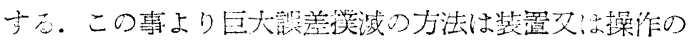

改変によりこの偶然的因子を制御寸る事であり，未知試 料の際にはこれを質的に変化させてやる事が必要であ る.このよ5にして得られた質的变化をわれわれは磙認 手段と称し，これによって始めて未知試料分析の操作㚘. 潗が得られ文誤差が检討可能となる。

分析は一ぺんの操作で終るるのでない，従って各操作

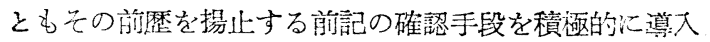
する必要があり, 又反応の化学性ばかりでなく対像の物 理性もまたその都度考慮さるべきものである。

この碓認手段の問題は更に分析法の標淮化汇末で発垡 する、いずれの方法が眐集法となるかに対しては少くと あ現在の分析法の中では巨大誤差の小さいといら事だけ が基準となる，分析法は発展する，その原動力は分析の 正確度，迅速，能率は分析法によって規定されるが，こ， れ等の要求は分析外上り与克られるという問題に志る. このように経济的汇重要な多くの分析室で行われている 分析法程一般に巨大誤差は小さいといい得る.

なふ永䒔報の理諭的取扱いは三井が，その基礎となる実 嘼站に data の集輯は荒川が担当した。

(京都薬科大学分析代学教窒)

\title{
ベリリウムの分析化学的研究（第 2 報） \\ ベリリウムを酸化物として定量する諎法の比較研究
}

\author{
(昭和 27 年 7 月 29 日受理)
}

秋山知行

ベリリウムを其壏の水溶液より水陵化物として沈淑さ せこ礼坴熱枃して酸化がリリウムとして定量を行了際， その処理にかなり学力と㬨間を要しその為結果汇も詋差 の原因を与兄ることが女る。文献によりその主要なもの を行すと次の经くである。

1. アンモニウム倎の存在でアンモニア水により沈激を

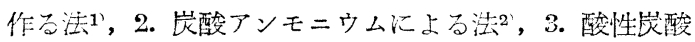
ナトリウムによる法 ${ }^{3} ， 4$. 塩化物を塩酸ニーテルで処理

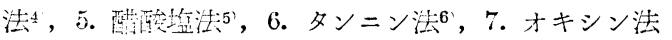
(ターオ士シキノyン法 $)^{6}$ ， 8. 沃素酸カリウム及び沃化 カリウムの混合物とに上る法?.

著都はこ礼等の内適当心もの 2,3 について比較研究 灾試みた。

\section{实 験 の 部}

\section{[A] 実験準備}

(1) 試料調製

試栕にはメルク製硝酸ベリリウムを蒸溜水に溶解して
調製する。即ち試料溶液 $10 \mathrm{cc}$ 中に存在与るべリリウレ

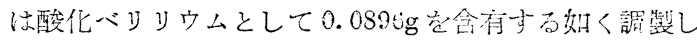
た.

（2）水酸化ぶリリウムの洗滥液について

著者の研究によれば洗临液は塩化アムモニウムによる 時は水酸化ベリリウムの沈激仁塩素イオンが残留する結 果，沈洪の乾燥後これを熱灼するに当って恐らくは心゙リ リウムの一部が塭化ベリリウムとなって芽華するために 定量結果が過少になる傾向がある。この点は Bleyer 改 び飯高一派の人ネ゙ が諭ずることの妥当なのを知った。 Britton ${ }^{9}$ ' の研究によると水酸化べリリウムは $\mathrm{pH}$ 值 5.70 で沈澱する。然し著者がアンモニア水を用いて沈澱させ ると $\mathrm{pH}$ 值 5.85 乃至 $\mathrm{pH} 6.75$ にて㴤潵完了点を示す ことが知られた。これ等の事突から泩渒液は $\mathrm{NH}_{4} \mathrm{NO}_{3}$ 溶液を採用した。 即ち $\mathrm{NH}_{4} \mathrm{NO}_{3} 10 \mathrm{~g}$ を蒸溜水 $100 \mathrm{cc}$ 中 に溶存せしわた約 $1 \%$ 溶液にブロムチモールブリュウ液 を加党たが青变し始める程度に $1.5 \mathrm{~N}-\mathrm{NH}_{4} \mathrm{OH}$ で中和し た。然もこの洗源液が酸性に变じた矛がある場合に常に 